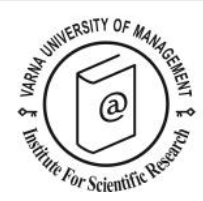

\title{
Market segmentation for wine tourism: Identifying sub-groups of winery visitors
}

\author{
Athina Nella ${ }^{1}$ and Evangelos Christou ${ }^{2 *}$
}

\author{
${ }^{1}$ Hellenic Open University, Greece \\ ${ }^{2}$ International Hellenic University, School of Economics \& Business, GR-5740o, Thessaloniki, Greece. E-mail: \\ echristou@ihu.gr \\ ${ }^{*}$ Corresponding author
}

\begin{abstract}
Notwithstanding the steady development of the international wine tourism industry, accurate relevant information and comparative surveys focusing on primary research appear inadequate in various wine-producing countries. Understanding the wine tourism market is vital for sustaining its further development. In addition to existing typologies for wine tourists, distinctions of winery visitors may provide a valuable tool to help wineries design and implement appropriate marketing tools. Accordingly, the aim of this study was to identify segment characteristics and variations among international and inland wine tourists based on a multinational sample of winery visitors in Greece; differences between experienced and inexperienced visitors, first-time and repeat visitors at a specific winery, individual and group visitors, and men and women were also examined. The empirical study was conducted at 18 wineries in the most significant wine-making areas in Greece, through 1,40o questionnaires forwarded to wineries for distribution among their customers through self-completion. The results confirm the existence of significant dissimilarities between domestic and international visitors in relation to pre-visit behaviour, primary knowledge and loyalty levels towards the winery's brands, visitation motives, spending attitudes, income, age distribution, perception of the winery experience and future behavioural intentions. Differences among these groups were also identified. The practical implications of the findings are discussed to assist winery managers and other wine tourism stakeholders implement a more customer-centric approach and improve strategic planning.
\end{abstract}

Key words: wine tourism segments, market knowledge, winery marketing

Citation: Nella, A. and Christou, E. (2021). Market segmentation for wine tourism: Identifying sub-groups of winery visitors. European Journal of Tourism Research 29, 2903 


\section{Introduction}

Since the early 1990s, the wine tourism market has experienced a substantial growth; according to O'Neil and Palmer (2004), "the wine-tourism phenomenon has taken on truly global proportions". Although the related academic literature has followed a similar evolution (Christou and Nella, 2010a; Chen et al., 2015; McGregor and Robinson, 2019), the wine tourism sector is characterised by scarcity of analytic information and comparative data though primary research (Van Westering and Niel, 2003; Carlsen, 2004; Alonso, 2009; Alebaki et al., 2015; Christou and Nella, 2016; Vo Thanh and Kirova, 2018; Gadelrab and Ekiz, 2019). Moreover, comparing data for diverse wine tourism destinations is further complicated due to significant differences among competing destinations (Getz and Brown, 2006; Barber et al., 2010) but also because of taxonomy concerns in relation to defining wine tourists (Carlsen et al., 1998; Charters and Ali-Knight, 2002; O'Neill and Palmer, 2004; Collins, 2005; Nella and Christou, 2014a; Gómez et al., 2019). Consequently, researchers are often constrained to subjective assessments rather than precise and justified evidence (e.g., Tassiopoulos et al., 2004; López-Guzmán et al., 2014; Ma et al., 2017; Dreyer, 2019).

This limited knowledge of target markets prevents an adequate grounding of marketing strategy development (Carlsen, 2004; Loubser, 2004; Sigala and Christou, 2007; Marzo-Navarro and PedrajaIglesias, 2010; Canovi et al., 2020). A clear understanding for geographic origin of consumer groups and sub-segments in the wine tourism sector is particularly significant because several evolving wine tourism destinations are focusing their promotion efforts on enticing incoming - international travellers (Williams and Dossa, 2003; O’Neill and Palmer, 2004; Quadri-Felitti and Fiore, 2013; Kim et al., 2016).

The main objective of the present study is to investigate differences between experienced and inexperienced winery visitors, first-time and repeat visitors at a specific winery, individual versus group visitors and men and women and to explore variations among domestic and international visitors in terms of critical aspects of their profiles and tourism and consumer behaviours, i.e., socio-demographic characteristics, visitation patterns at a winery, relationship with wine and wine tourism, pre-visit attitudes, post-visit evaluations, initial knowledge and winery brand loyalty, visitation motives, spending patterns, income, age distribution, satisfaction and assessment of the visitation experience and future behavioural attitudes.

Prospective identification of potential similarities and differences will help winery owners and managers re-examine their current marketing strategies and assist the design of future plans with a more customer-centric orientation. Further research on winery visitor market segments is fundamental to further support the growth of wine tourism (Beames, 2003; Marzo-Navarro and Pedraja-Iglesias, 2010; Alonso et al., 2020) and to assist the wineries' efficient operation as tourist attractions (Cohen and BenNun, 2009; Chen and Sasias, 2014; Ferreira and Hunter, 2017; Pakhalov and Rozhkova, 2020). QuadriFelitti and Fiore (2012) note that although the relevant literature is mounting, a gap in knowledge remains between the needs and demands of wine tourists about the overall experience from a successful wine tourism destination, and the actual offering of wine tourism providers. Beyond informing stakeholders in the wine tourism market, academics may relate the outcomes of this survey to data obtained from other geographical regions to identify regional or global characteristics and trends of the wine tourism market.

\section{Literature Review}

According to literature, a standardised type of wine tourists cannot be clearly identified (Ali-Knight and Charters, 2001; Bruwer et al., 2001; Mitchell and Hall, 2006; Bruwer and Alant, 2009; Quadri-Felitti and 
Fiore, 2016). Although various typologies have been proposed (e.g., Hall, 1996; Corigliano, 1996; Lockshin and Spawton, 2001; Charters and Ali-Knight, 2002; Williams and Dossa, 2003; Yuan et al., 2005; Brown et al., 2007; Galloway et al., 2008; Houghton, 2008; Yuan et al., 2008; Bruwer and Alant, 2009; Alebaki and Iakovidou, 2010; Marzo-Navarro and Pedraja-Iglesias, 2010; Bitsani and Kavoura, 2012; Nella and Christou, 2014b; Thomas et al., 2016; Chatzigeorgiou and Simeli 2017; Festa et al., 2020), few authors have distinguished wine tourists according to criteria such as origin, visitation pattern, experience in wine tourism or gender. According to McNamara and Cassidy (2015) this type of knowledge may prove useful for wineries that find it difficult to determine which typologies from the global wine tourism literature correspond to their visitors. Moreover, this type of knowledge may reveal important aspects of the nature, structure and positioning approaches most efficient for developing wine tourism effectively at specific geographical areas or regions.

Williams and Dossa (2003) examined the incoming visitors of British Columbia's wine tourism locations, while Alonso et al. (2007a,b) investigated potential dissimilarities among wine tourists from diverse ages of local and international travellers in New Zealand. Alonso et al. identified significant variances between these groups in in relation to winery spending patterns, age, level of education and personal income. In the U.S.A., Bruwer and Thach (2013) identified significant dissimilarities among first-time visitors and loyal ones, as well as between local and out-of-state travellers, related to the ways adopted for obtaining information necessary for planning a trip to a wine tourism destination. The authors also studied the ways that situational and socio-demographic variables influence and shape such dissimilarities.

Several segmentation parameters appear in wine tourism studies to have been adopted in order to identify alternative typologies of wine tourists. Hall (1996), in a landmark study, developed a segmentation approach focusing on insights from winery managers and resulted to distinct market segments: "wine lovers", "wine interested" and "curious". Ali-Knight and Charters (1999) adopted the same approach and reached to similar conclusions, whereas other researchers attempted to investigate further the characteristics of the three segments suggested by Hall by examining participants in wine festivals and winery customers (Brown et al., 2007; Houghton, 2008; Chatzigeorgiou et al., 2009; MarzoNavarro and Pedraja-Igglesias, 2010; Chen et al., 2015; Del Chiappa et al., 2018; Giannopoulos et al., 2020). Other attempts explored various sociodemographic variables (age group, income and education level, and sex) to develop wine tourist typologies (Carlsen, 2004; Montella, 2017); in relation to personal income, Dodd and Bigotte (1997) concluded that this variable may be a highly significant moderator of wine consumption and winery visitation, while other researchers suggested that wine tourists typically appear to belong to higher age groups and to possess high product-involvement and superior knowledge about wine in general (King and Morris, 1997; Heaney, 2003; Charters and Pettigrew, 2006; Chatzigeorgiou et al., 2019; Christou, 2002, 2011; López-Guzmán et al., 2014; Scorrano et al., 2019; Amanatidis et al., 2020).

Bruwer et al. (2001) in a pioneering study concluded that even wine tourists with demographic similarities may express essential differences in other segmentation characteristics, such attitudes towards wine, product involvement and knowledge, lifestyles or wine consumption patterns and occasions. Subsequent authors claimed that psychographic segmentation variables can provide a complementary and more solid segmentation basis, by correlating wine consumption and wine tourism with characteristics like visitation motives, lifestyle, activities, personal values and skills (Thach and Olsen, 2004; Getz and Brown, 2006; Galloway et al., 2008; Liu et al., 2015; López-Guzmán, et al., 2016; Fotiadis and Williams, 2018; Smyczek et al., 2020). Corigliano (1996) developed four alternative segments centred on the lifestyles and attitudes of Italian wine tourists. In this vein, other researchers 
in a number of studies have attempted to adopt tourism motives for segmenting the wine tourism market (Lockshin and Spawton, 2001; Williams and Dossa, 2003; Yuan et al., 2005; Valachis et al., 2008; Alebaki and Iakovidou, 2010; Martins, 2016; Chatzigeorgiou et al., 2017).

Charters and Ali-Knight (2002) extended Hall's typology (1996) by adopting "interest in wine" and "wine knowledge" as segmentation variables, and further developed two additional market segments: the "wine connoisseur" and the "hanger-on". The "wine connoisseur" segment exhibits high productinvolvement with wine expressed by enhanced wine interest and significant wine knowledge and understanding; the "hanger-on" appears to be a tourist not interested specifically for wine tourism and hence, travels to a wine destination without evident interest in wine but in the framework of an excursion (i.e., participating in a tour). Furthermore, Charters and Ali-Knight (2002) redefined the "wine curious" group (those with limited knowledge about wine) as "wine novices" and described interesting characteristics of this segment. Taking another approach, Galloway et al. (2008) explored visitors' personality characteristic of "sensation seeking" and provided an alternative psychographic segmentation of the wine tourism market. Some researchers adopted as segmentation approach the concept of product-involvement and applied it to the wine market (Lockshin and Spawton, 2001; Brown et al., 2007; Yuan et al., 2008; Chatzigeorgiou and Simeli, 2017; Christou et al., 2018; Daskalaki et al., 2020), and extended it to a limited degree to involvement with wineries and with wine tourism.

According to available literature of wine tourism, it may be suggested that the evolution of the wine tourism research points to the direction that any comprehensive generalisation of the profile of wine tourists has not been established yet. Wine tourism may be considered as a type of cultural tourism (Lyons and Branston, 2006; Marzo-Navarro and Pedraja-Iglesias, 2010; Mavragani et al., 2019) with an expanding attractiveness to an increasing number of diverse tourists internationally (Valeri, 2016; Volgger et al., 2017; IJspeert and Hernandez-Maskivker, 2020); hence, it may be suggested that researchers should study further current and future market trends and explore in more depth the changing profiles of wine tourists.

Empirical wine tourism research at the European level is relatively limited (Christou and Nella, 2010a; Charters and Menival, 2011; De Ridder and Vanneste, 2020), especially given its wine-producing and tourism potential. In particular, studies concerning wine tourists are extremely scarce in Greece; thus, it was considered as meaningful to conduct a large-scale empirical study.

\section{Methodology}

The overall objective of the work reported here was to investigate the consecutive stages of the experience in wine tourism (pre-visit, visit, post-visit), portray the characteristics of wine tourists, and subsequently developed a segmentation approach. The empirical study was conducted at 18 wineries in the most significant wine-making areas in Greece, through 1,400 questionnaires forwarded to wineries for distribution among their customers through self-completion. Convenience sampling was chosen because the total population of winery visitors in Greece is not officially recorded or estimated. Similar approaches have been used by other authors in this field (e.g., Jaffe and Pasternak, 2004; Alonso et al., 2007b; Dawson et al., 2011; Bitsani and Kavoura, 2012; Revilla Hernández et al., 2016; Chatzigeorgiou and Christou, 2019, 2020). Eventually, 528 usable questionnaires were obtained; 359 completed by domestic visitors and 169 by international ones originating out of 18 different countries. SPSS 20.0 was used for all statistical analyses. In limited cases of missing data (less than $4 \%$ of the usable questionnaires), items were analysed based on a smaller sample than the entire sample of 528 usable responses. 
The study was quantitative and the research instrument used was a structured questionnaire, consisting of four parts: a) respondent's association to wine in general, before travelling to the winery (motives, pre-visit feelings for the winery's products as well as for the winery itself, previous knowledge and experiences, personal anticipations and potential expectations); b) assessment of the present visitation experience (encounter-specific service quality, overall satisfaction); c) post-visit views and future behavioural intentions (based on Consumer-Based Brand Equity theory or CBBE, i.e., feelings in relation to possible brand extensions and price elasticity, and post-visit behavioural attitude) and d) personal socio-demographic information (employment, sex, age, personal income, education, and average monthly spending for wine purchases).

The respondents were requested to reveal the visit motives by selecting the appropriate ones out of a list of eight potential winery visitors' motivations proposed by Alant and Bruwer (2004): purchasing wine, tasting different wine, obtaining knowledge for the winery's products, interacting with the winemaker or the oenologist, touring the winery installations and understanding the winery operations and ambience, socialising and being part of an organised group visit, having a short break or leisure outing, and unclassified or other motives.

Responses about sample unit personal information were recorded by using categorical measures (i.e., demographic), but all other questions were in the form of 7-point Likert scales (where 1 was "strongly disagree" and 7 signified "strongly agree"), or - in a limited number of cases - 7-point semantic differential scales. Multi-item measurement was used for product category involvement, pre-visit feelings, encounter-level service quality, overall satisfaction, Consumer-Based Brand Equity measurements, brand attachment, potential brand extensions, price elasticity and future behavioural intents. Content validity was assured through using and adapting appropriately measures whose validity was already established in previous studies.

In particular, for the measurement of product category involvement, a four-item scale was adapted from the survey of Yoo and Donthu (2001). Transaction-level service quality at the winery was recorded through a 14-item scale suggested by Christou and Nella (2010b), while overall satisfaction from the winery visitation was recorded in 4 Likert scale statements modified from the Fisher and Price (1991) measures. Brand attachment was measured through the scale of Thomson et al. (2005), while Consumer-Based Brand Equity was recorded on the multi-dimensional 10-item scale developed by Yoo and Donthu (2001). Measurement scales regarding attitudes concerning potential brand extensions and price elasticity practices were modified from those proposed by Wang et al. (2008). Last, pre-visit feelings were recorded through two measures, the first related to attitudes towards the specific winery while the second recorded attitudes related to the specific winery's products, and future behavioural intents were recorded in three items: intent to visit the winery again, word of mouth communications, and enrichment of product-category choices.

\section{Findings and discussion}

\section{Sample description and reliability of measurement scales}

Based on the 528 respondents among winery visitors, a rather balanced depiction of male and female sample units was observed, respectively $48 \%$ and $52 \%$. Most of winery visitors examined were from Greece $(64 \%)$, although the survey population was of international nature as 190 of them originated from 18 other countries, mostly from the United Kingdom, France, the U.S.A., Spain, Germany and Italy. Almost 31\% out of all respondents were first-timers, i.e., this was their first visit to a winery, and $44 \%$ were visiting within a group; $23 \%$ of the respondents had visited the specific winery again in the past 
(Table 1). Overall, common motives for visiting the winery included learning about wine and winemaking, tasting wines and experiencing the environment of a winery.

Table 1. Sample description

\begin{tabular}{|c|c|c|c|c|c|c|c|c|c|}
\hline Gendei & & Origin & & Firs & ners & Mode & visit & Rep & \\
\hline Male & Female & Domestic & Foreign & Yes & $\mathrm{No}$ & Group & Individual & Yes & $\mathrm{No}$ \\
\hline $48 \%$ & $52 \%$ & $64 \%$ & $36 \%$ & $31 \%$ & $69 \%$ & $44 \%$ & $56 \%$ & $23 \%$ & $77 \%$ \\
\hline
\end{tabular}

With respect to the sociodemographic characteristics of the sample, just over one third of the wineries' visitors (34\%) were over 45 years of age, less than half $(49 \%)$ had monthly incomes exceeding 1,300 euros, and $36 \%$ indicated that their average monthly spend on wine purchases was over 50 euros. In terms of education, most of respondents claimed to have obtained a first degree (65\%) while an additional $16 \%$ possessed a postgraduate diploma.

All multi-item scales used to test differences among sub-groups were evaluated in terms of internal reliability (Table 2). Cronbach's alpha was estimated to be above acceptable levels $(\alpha>0.7)$ for all constructs: pre-visit attitudes $(\alpha=0.893)$, product involvement $(\alpha=0.829)$, service quality $(\alpha=0.966)$, satisfaction $(\alpha=0.904)$, CBBE $(\alpha=0.922)$, brand attachment $(\alpha=0.943)$, brand extensibility $(\alpha=0.918)$ and price flexibility $(\alpha=0.829)$.

Table 2. Reliability of measurement scales

\begin{tabular}{ll}
\hline Scales & Cronbach's alpha \\
\hline pre-visit attitudes & 0.893 \\
product involvement & 0.829 \\
service quality & 0.966 \\
satisfaction & 0.904 \\
CBBE & 0.922 \\
brand attachment & 0.943 \\
brand extensibility & 0.918 \\
price flexibility & 0.829 \\
\hline
\end{tabular}

\section{Domestic and international visitors}

Cross-tabulations and chi-square tests were used to identify statistically significant differences in visitation patterns, gender, motives, age, education level, personal income, and employment. Significant differences among international and domestic respondents were identified through chi-square tests (Table 3). Group visitation was one of the examined variables because often winery visitation in Greece is associated to visitors from other countries. Findings confirmed previous studies (Chatzigeorgiou \& Christou, 2016) suggesting that foreign visitors of wineries in Greece tend to be part of an organised group or tour $(61 \%)$; chi-square test results established a statistically significant difference among these two groups (Table 3 ).

International visitors had significantly higher percentages of female participation (61\% versus $45 \%$ ). Respondents were also asked to indicate their major motives. Significantly higher percentages of domestic visitors appeared exhibited a strong motivation to purchase wines while at the winery, interact with the winemaker or the oenologist, and participate in an organised tour of the winery or experience the winery environment and ambience. By contrast, higher percentages of international visitors 
appeared motivated to participate in a group activity and have an excursion. The remaining motives did not differ significantly between the two groups.

Table 3. Significant differences among domestic and international visitors*

\begin{tabular}{|c|c|c|c|c|}
\hline & Visitors & & & \\
\hline Comparison Basis & Domestic & International & Chi-square test & Sign. \\
\hline Visitation within group (\%) & $34 \%$ & $58 \%$ & $27.409, \mathrm{P}=0.000$ & $\checkmark$ \\
\hline Gender (\% of women) & $45 \cdot 4 \%$ & $60.5 \%$ & $9.915, \quad P=0.002$ & $\checkmark$ \\
\hline Motive 1 : buy wines (\%) & $49 \%$ & $40 \%$ & $4.453, P=0.035$ & $\checkmark$ \\
\hline Motive 4 : meet producer $(\%)$ & $43 \%$ & $30 \%$ & $8.580, P=0.003$ & $\checkmark$ \\
\hline $\begin{array}{l}\text { Motive 5: experience the } \\
\text { winery environment (\%) }\end{array}$ & $71 \%$ & $58 \%$ & $8.820, P=0.003$ & $\checkmark$ \\
\hline Motive 6: group visit (\%) & $26 \%$ & $40 \%$ & $10.432, P=0.001$ & $\checkmark$ \\
\hline Motive 7: excursion (\%) & $33 \%$ & $51 \%$ & $15.141, P=0.000$ & $\checkmark$ \\
\hline \multicolumn{5}{|l|}{ Age groups } \\
\hline $18-25$ & $15.7 \%$ & $9.6 \%$ & & \\
\hline $26-34$ & $26.4 \%$ & $17.4 \%$ & $19.417, P=0.002$ & $\checkmark$ \\
\hline $35-44$ & $23.4 \%$ & $35 \cdot 9 \%$ & & \\
\hline $45-54$ & $23.4 \%$ & $18.6 \%$ & & \\
\hline $55-64$ & $7 \cdot 7 \%$ & $13.8 \%$ & & \\
\hline $65+$ & $3 \cdot 3 \%$ & $4.8 \%$ & & \\
\hline \multicolumn{5}{|l|}{ Income groups } \\
\hline $800 €$ and under & $23 \cdot 3 \%$ & $11.1 \%$ & & \\
\hline $801-1,300 €$ & $35 \cdot 9 \%$ & $15.0 \%$ & $45.139, \mathrm{P}=0.000$ & $\checkmark$ \\
\hline $1,301-1,800 €$ & $19.6 \%$ & $31.4 \%$ & & \\
\hline $1,801-2,500 €$ & $12.0 \%$ & $23.5 \%$ & & \\
\hline Over $2,500 €$ & $9 \cdot 3 \%$ & $19.0 \%$ & & \\
\hline \multicolumn{5}{|l|}{ Monthly wine spending } \\
\hline $20 €$ and under & $29.2 \%$ & $13.0 \%$ & $30.327, P=0.000$ & $\checkmark$ \\
\hline $21-50 €$ & $40.4 \%$ & $32.3 \%$ & & \\
\hline $51-80 €$ & $18.6 \%$ & $31.1 \%$ & & \\
\hline $81-120 €$ & $6.4 \%$ & $14 \cdot 3 \%$ & & \\
\hline Over $120 €$ & $5 \cdot 4 \%$ & $9 \cdot 3 \%$ & & \\
\hline
\end{tabular}

*examined with Chi-square tests

No significant differences were observed among international and domestic visitors in relation to previous wine tourism experiences, previous visits at the specific winery, on-site wine tasting and wine purchases at the cellar door, nor were there significant differences in educational level or type of occupation. Interestingly enough, both international and domestic respondents included large groups of university graduates ( $67 \%$ and $58 \%$ respectively), while another $17 \%$ were postgraduate or doctorate degree holders. The two sub-samples showed a significant difference in age distribution. Domestic respondents were of mostly younger age (18-34), as well as 45-54 years old, whereas international visitors' aged ranged mostly 35-44 and 55-64 years.

Significant differences were also evident in income levels and wine spending. International visitors appeared to have higher financial status: $43 \%$ reported a personal monthly income over 1,80o euros, whereas the relevant percentage of domestic respondents was just over $25 \%$. International respondents 
were also heavier wine spenders, as evidenced by the significantly higher percentage spending more than 8 o euros, i.e., $24 \%$ versus $12 \%$. Domestic visitors, by contrast, exhibited larger groups of personal monthly incomes under 1,300 euros $(56 \%$ as opposed to $29 \%)$ and monthly wine purchases under 20 euros (32\% as opposed to $17 \%)$.

The remaining responses were then analysed, describing the visitors' relationship with wine and wine tourism, namely levels of product-involvement, satisfaction with previous wine tourism experiences and pre-visit attitudes for the winery's products, and pre-visit expectations about the winery visitation experience. These variables were measured with 7-point Likert scales or through 7-point semantic differential scales; t-tests were calculated, and significant differences were identified (Table 4).

The $t$-tests did not reveal any significant differences between domestic and international visitors in the items used to measure product-involvement (i.e., wine consumption, involvement, expertise on wine issues and interest in wine). In addition, there was no difference in the average involvement level computed from the four measurement items. Similarly, no differences were found in terms of satisfaction with past experiences of wine tourism activities and pre-visit experience anticipations in relation to the present winery visit.

Another interesting outcome was the identification of pre-visit feelings for the winery and its products, and the relationship of respondents to the winery's products, i.e., awareness and loyalty levels; pre-visit attitudes of domestic visitors were more positive compared to international visitors'. This was probably due to the fact that domestic visitors also exhibited better knowledge of the winery's products and higher initial loyalty levels.

In terms of service quality perceptions, $t$-tests did not reveal any statistically significant differences among the two main visitor groups. By contrast, significant differences were found in satisfaction with the winery visit; domestic respondents exhibited significantly higher satisfaction levels. Additional differences were observed in the post-visit evaluations of CBBE for the winery's brands. Domestic respondents exhibited stronger intention to visit again the winery in the future, to spread positive word of mouth about the winery, and to purchase the winery's products after the winery visit. The variable that measured visitor attitudes towards brand extensibility practices also differed significantly, whereas there was no significant difference for price flexibility practices.

Experienced and inexperienced visitors and first-time and repeat visitors at the specific winery Experienced visitors represented $66 \%$ of the respondents. As shown in Table 4, the only parameters in which experienced and inexperienced winery visitors differed were involvement levels and pre-visit awareness of the winery's products and brands. Expectations, service quality evaluations, satisfaction, Consumer-Based Brand Equity, feelings towards brand extension, price elasticity, and future behavioural intentions, did not significantly differ among the two groups.

First-time visitors at the specific winery (79\%) had significantly lower expectations before their winery visit, knowledge and brand loyalty for the winery's products. Additionally, they had less positive previsit feelings for the winery and its products, lower involvement with wine, lower evaluations of CBBE and less positive feelings for potential future brand extensions. By contrast, future behavioural intentions concerning revisit and creation of word of mouth were better among repeat visitors at the specific winery. 
Table 4. Statistically significant differences highlighted by t-tests

\begin{tabular}{|c|c|c|c|c|c|}
\hline Sub-groups & Variable & $\begin{array}{l}\text { Average } \\
\text { scores }\end{array}$ & $t$ & $d f$ & $\begin{array}{l}\text { Sig. } \\
(<0.05)\end{array}$ \\
\hline \multirow{9}{*}{$\begin{array}{l}\text { Domestic/international } \\
\text { visitors }\end{array}$} & Pre-visit attitudes & $4.48 / 3.77$ & 5.974 & 515 & 0.000 \\
\hline & Pre-visit awareness & $3.89 / 3.36$ & $3 \cdot 571$ & 515 & 0.000 \\
\hline & Pre-visit loyalty & $4.13 / 3.26$ & $5 \cdot 706$ & 515 & 0.000 \\
\hline & Satisfaction level & $5.69 / 5.45$ & 2.294 & 515 & 0.023 \\
\hline & CBBE & $4.94 / 4.45$ & 4.849 & 515 & 0.000 \\
\hline & Attitudes towards extensibility & $5.07 / 4.60$ & 4.177 & 515 & 0.000 \\
\hline & Intention to enhance preferences & $5 \cdot 56 / 4.76$ & 6.052 & 515 & 0.000 \\
\hline & $\begin{array}{l}\text { Intention to create word of } \\
\text { mouth }\end{array}$ & $5.77 / 5.17$ & $4 \cdot 515$ & 515 & 0.000 \\
\hline & Revisit intention & $5.38 / 4.68$ & 5.170 & 515 & 0.000 \\
\hline \multirow{2}{*}{$\begin{array}{l}\text { Experienced/inexperienced } \\
\text { visitors }\end{array}$} & Involvement level & $4.38 / 3.41$ & 8.222 & 515 & 0.000 \\
\hline & Pre-visit awareness & $3.87 / 3.42$ & 3.042 & 515 & 0.002 \\
\hline \multirow{14}{*}{$\begin{array}{l}\text { Repeat visitors/first-time } \\
\text { visitors at the specific winery }\end{array}$} & Involvement level & $4.45 / 3.94$ & 3.533 & 515 & 0.000 \\
\hline & Pre-visit expectations & $5.82 / 5.46$ & 2.987 & 515 & 0.003 \\
\hline & Pre-visit awareness & $4.47 / 3.52$ & $5 \cdot 589$ & 515 & 0.000 \\
\hline & Pre-visit loyalty & $4.74 / 3.62$ & 6.466 & 515 & 0.000 \\
\hline & Pre-visit attitudes & $4.91 / 4.07$ & 6.179 & 515 & 0.000 \\
\hline & Evaluation of service quality & $6.00 / 5.74$ & 2.388 & 515 & 0.017 \\
\hline & Satisfaction levels & $5.89 / 5.54$ & 2.844 & 515 & 0.005 \\
\hline & Brand attachment & $5.39 / 4.94$ & 3.391 & 515 & 0.001 \\
\hline & CBBE & $5.34 / 4.64$ & 6.019 & 515 & 0.000 \\
\hline & Feelings towards brand extension & $5.44 / 4.77$ & 5.103 & 515 & 0.000 \\
\hline & Attitudes towards price flexibility & $4.94 / 4.53$ & 2.815 & 515 & 0.005 \\
\hline & Revisit intention & $5.78 / 4.99$ & 5.031 & 515 & 0.000 \\
\hline & $\begin{array}{l}\text { Intention to create word of } \\
\text { mouth }\end{array}$ & $5.96 / 5.47$ & 3.217 & 515 & 0.001 \\
\hline & Intention to enhance preferences & $5.77 / 5.18$ & 3.784 & 515 & 0.000 \\
\hline \multirow[t]{13}{*}{ Individual/group visitors } & Involvement level & $4.15 / 3.89$ & 2.132 & 515 & 0.033 \\
\hline & Consumption frequency & $4.43 / 3.92$ & 3.285 & 515 & 0.001 \\
\hline & Pre-visit expectations & $5.64 / 5.39$ & 2.521 & 515 & 0.012 \\
\hline & Pre-visit attitudes & $4.41 / 4.01$ & 3.537 & 515 & 0.000 \\
\hline & Pre-visit awareness & $3.85 / 3.53$ & 2.269 & 515 & 0.024 \\
\hline & Pre-visit loyalty & $4.04 / 3.59$ & 2.999 & 515 & 0.003 \\
\hline & Evaluation of service quality & $5.92 / 5.61$ & $3 \cdot 346$ & 515 & 0.001 \\
\hline & Satisfaction levels & $5.80 / 5.36$ & $4 \cdot 355$ & 515 & 0.000 \\
\hline & CBBE & $4.93 / 4.58$ & $3 \cdot 574$ & 515 & 0.000 \\
\hline & Feelings towards brand extension & $5.08 / 4.67$ & 3.826 & 515 & 0.000 \\
\hline & Revisit intention & $5.39 / 4.83$ & 4.339 & 515 & 0.000 \\
\hline & $\begin{array}{l}\text { Intention to create word of } \\
\text { mouth }\end{array}$ & $5.87 / 5.14$ & $5 \cdot 905$ & 515 & 0.000 \\
\hline & Intention to enhance preferences & $5.50 / 5.02$ & 3.647 & 515 & 0.000 \\
\hline \multirow[t]{4}{*}{ Men/women } & Pre-visit loyalty & $4.03 / 3.71$ & 2.072 & 482 & 0.039 \\
\hline & Wine expertise & $3.45 / 2.93$ & 3.530 & 481 & 0.000 \\
\hline & Attitudes towards the winery & $4.56 / 4.94$ & -2.813 & 482 & 0.005 \\
\hline & Service quality evaluation & $5.72 / 6.03$ & -3.491 & 482 & 0.001 \\
\hline
\end{tabular}


Individual and group visitors

Group visitors (41\%) had lower levels of involvement and consumption frequency than individual visitors, as shown in Table 4. Group visitors also had significantly lower expectations before the winery visitation, knowledge and brand loyalty levels for the winery's products, and less positive attitudes. The two groups did not differ in terms of satisfaction with previous wine tourism experiences. In terms of post-visit behavioural intentions, group visitors appeared less willing to visit again in the future the specific winery, to spread positive word of mouth concerning their visit, and to augment their wine preferences. Finally, group visitors had lower levels of CBBE and less positive attitudes towards future brand extensibility practices.

\section{Men and women}

As mentioned earlier, the total sample included almost equal groups of male and female respondents. Only four differences proved statistically significant (Table 4). Men had significantly higher scores for agreement with the statement that they considered themselves as wine experts as well as higher previsit brand loyalty to the winery's products. Women, by contrast, had more positive pre-visit feelings for the specific winery and more positive evaluations of service quality during their winery visit.

\section{Conclusions and practical implications}

As noted by Williams and Dossa (2003), the lack of detailed surveys on non-domestic travellers advocates the presence of potential prospects to reinforce the international facet of wine tourism. Hence, the research reported here, and the differences examined herein, may imply useful marketing suggestions for managers of wineries as well as for wine tourism planers. The identification of different visitors' motives may be exploited to better develop proper winery experiences and services that satisfy travellers' needs and demands. For instance, domestic visitors tend to be more inclined to purchase wines while at the winery, to socialise with the winemaker or the oenologist, and participate in organised experiential winery tours. International visitors, by contrast, seem more interested to be part of a package visit at a winery or as an excursion that was part of their trip to Greece without this being their main purpose of visit to the country. Such facets of wine tourists' intentions may assist winery marketers to enhance and improve winery experiences accordingly; for example, wineries could offer international visitors the option to combine the winery experience with ecotourism activities based on the vineyards.

Moreover, the higher financial status of international visitors and their apparent lower satisfaction with the winery visitation may present a market opportunity for developing superior wine tourism experiences and tours. For instance, wineries may investigate how organised visit experiences could be enhanced, perhaps through limiting the members per package or through incorporating additional services of high value. Such changes would inevitably entail charging higher prices for smaller groups, but this would most likely be acceptable for a number of visitors. By contrast, wineries may want to design loyalty programs and offer discounts or special offers for direct purchases at the cellar door to attract domestic visitors, who were more likely to visit to buy wines but had relatively lower incomes and wine spending.

The pre-visit feelings towards the brand and the post-visit behavioural intents of respondents may present an additional opportunity for winery marketers; they may pursue approaches to augment previsit liking and knowledge for a winery and its products, which were considerably poorer among international visitors. Thus, poorer attitudes and awareness among international visitors could be further evidence of the low extroversion of Greek brands in the international wine market. One way to increase awareness is by attempting to increase exports through collaboration with appropriate 
distribution channels, participation in international wine exhibitions, greater advertising activity and improved publicity. Another option to increase awareness among foreign tourists is to develop collaborations with other tourism enterprises. For instance, partnerships with airline companies may assist visitors to develop awareness for the wine brands of the destination they are going to visit. Collaboration with local hotels and restaurants serving specific wine brands and distribution of advertising material could urge tourists to perform an unplanned winery visit. Increasing the availability of promotional material in social media and at any other potential sources of tourist information may support significantly such efforts.

According to previous surveys, word of mouth is a significant and influential source of information for potential wine tourists (Dodd, 1998, 1999; Christou, 2011). Based on the findings of the research reported here, domestic wine tourists tend to be more willing to revisit the winery and spread favourable word of mouth; hence, winery marketers should consider that satisfied visitors may assist the winery achieve repeat visitations, enhance the equity of its brands and enlarge its pool of visitors and loyal customers. Wineries need to cautiously investigate the profiles and features of their visitors, to identify their demands and anticipations and developed customised or personalised winery visitation experiences. Moreover, wine tourism market understanding may assist marketers to develop and take decisions for strategic approaches for targeting the most suitable market segments and develop effective positioning practices.

\section{Limitations of the study}

This study is based on evidence from a single country and a convenience sample, although some of its findings may reflect the current situation of wine tourists at other national settings. The generalisation of these findings is definitely subject to further research at the regional, national or even global level. In any case, differentiations among countries and the evolution of these characteristics should be periodically monitored to ensure updated data. As wine tourism appeals to an increasing number of people, the respective market will likely transform further, and wine tourism behaviour will constantly evolve.

Another limitation of this study is the apparently simplistic nature of segmenting winery visitors using the above-mentioned characteristics compared to the widely applied complex segmentation criteria. However, the availability of these findings can help stakeholders clearly describe the market and enhance market knowledge.

\section{References}

Alant, K., \& Bruwer, J., (2004). Wine tourism behaviour in the context of a motivational framework for wine regions and cellar doors. Journal of Wine Research, 15 (1), 27-37.

Alebaki, M., \& Iakovidou, O. (2010). Segmenting the Greek wine tourism market using a motivational approach. New Medit, 9(4), 31-40.

Alebaki, M., Menexes, G., \& Koutsouris, A. (2015). Developing a multidimensional framework for wine tourist behavior: Evidence from Greece. Wine Economics and Policy, 4(2), 98-109, http://dx.doi.org/10.1016/j.wep.2015.11.002.

Ali-Knight, J., \& Charters, S. (2001). The winery as educator: Do wineries provide what the tourist needs? Australian and New Zealand Wine Industry Journal, 16(6), 79-86.

Alonso, A.D., Fraser, R., \& Cohen, D. (2007a). Does age matter? How age influences the winery experience. International Journal of Culture, Tourism and Hospitality Research, 1(2), 131-139. 
Alonso, A.D., Fraser, R., \& Cohen, D. (2007b). Investigating differences between domestic and international winery visitors in New Zealand. International Journal of Wine Business Research, 19(2), 114-126.

Alonso, A.D., Sheridan L., \& Scherrer, P. (2008). Importance of tasting rooms for Canary Islands' wineries. British Food Journal, 110(10), 977-988.

Alonso, A.D. (2009). Are travellers interested in wine tourism in New Zealand? International Journal of Culture, Tourism and Hospitality Research, 3(1), 13-24.

Alonso, A.D., Kok, S., \& O'Brien, S. (2020). Sustainable wine tourism development through the lens of dynamic capabilities and entrepreneurial action: an exploratory four-region perspective. Tourism Recreation Research, 45(3), 401-419. DOI: 10.1080/02508281.2020.1745000.

Amanatidis, D., Mylona, I., Mamalis, S., \& Kamenidou, I. (2020). Social media for cultural communication: A critical investigation of museums' Instagram practices. Journal of Tourism, Heritage \& Services Marketing, 6(2), 38-44.

Barber, N., Taylor D.C., \& Deale, C.S. (2010). Wine tourism, environmental concerns, and purchase intention. Journal of Travel \& Tourism Marketing, 27(2), 146-165.

Beames, G. (2003). The rock, the reef and the grape: The challenges of developing wine tourism in regional Australia. Journal of Vacation Marketing, 9(3), 205-212.

Bitsani, E., \& Kavoura, A. (2012). Connecting oenological and gastronomical tourisms at the Wine Roads, Veneto, Italy, for the promotion and development of agrotourism. Journal of Vacation Marketing, 18(4), 301-312.

Brown, G.P., Havitz, M.E., \& Getz, D. (2007). Relationship between wine involvement and wine-related travel. Journal of Travel \& Tourism Marketing, 21(1), 31-46.

Bruwer, J. (2002). The importance and role of the winery cellar door in the Australian wine industry: Some perspectives. The Australian and New Zealand Grapegrower and Winemaker, August, 96-99.

Bruwer, J., \& Alant, K. (2009). The hedonic nature of wine tourism consumption: an experiential view. International Journal of Wine Business Research, 21(3), 235-257.

Bruwer, J., \& Thach, L. (2013). Wine tourists' use of sources of information when visiting a USA wine region. Journal of Vacation Marketing, 19(3), 221-233.

Bruwer, J., Li, E., \& Reid, M. (2001). Wine-related lifestyle segmentation of the Australian domestic wine market. Australian and New Zealand Wine Industry Journal, 16(2), 104-108.

Canovi, M., Mordue, T., \& Lyon, A. (2020). The impact of wine tourism involvement on winery owners' identity processes. Tourism Planning E Development, 17(5), 573-590. DOI: 10.1080/21568316.2020. 1730945.

Carlsen, J., Dowling, R., \& Cowan, E. (1998). Wine tourism marketing issues in Australia. International Journal of Wine Marketing, 10(3), 23-32.

Carlsen, J. (2004). A review of global wine tourism research. Journal of Wine Research, 15 (1), pp. 5 -13.

Charters, S., \& Ali-Knight, J. (2002). Who is the wine tourist? Tourism Management, 23(3), 311-319.

Charters, S., \& Menival, D. (2011). Wine tourism in Champagne. Journal of Hospitality and Tourism Research, 35(1), 102 -118.

Charters, S., \& Pettigrew, S. (2006). Product involvement and the evaluation of wine quality. Qualitative Market Research: An International Journal, 9(2), 181-193.

Chatzigeorgiou, C., \& Christou, E. (2016). Destination branding and visitor brand loyalty: Evidence from mature tourism destinations in Greece. Tourismos: An International Multidisciplinary Journal of Tourism, 11(5), 102-123.

Chatzigeorgiou, C., \& Christou, E. (2019). Social media in tourism marketing: Travellers' attitudes and encounters. TOURMAN 2019 Conference Proceedings. Thessaloniki: Greece (27 October 2019): pp. 164-173. 
Chatzigeorgiou, C., \& Christou, E. (2020). Adoption of social media as distribution channels in tourism marketing: A qualitative analysis of consumers' experiences. Journal of Tourism, Heritage E Services Marketing, 6(1), 25-32, http://dx.doi.org/10.5281/zenodo.3603355.

Chatzigeorgiou, C., Christou, E., Kassianidis, P., \& Sigala, M. (2009). Examining the relationship between emotions, customer satisfaction and future behavioural intentions in agrotourism. Tourismos: An International Multidisciplinary Journal of Tourism, 4(4), 145-161.

Chatzigeorgiou, C., Christou, E., \& Simeli, I. (2017). Delegate satisfaction from conference service quality and its impact on future behavioural intentions. Published in: 5 th International Conference on Contemporary Marketing Issues ICCMI, June 21-23, 2017 Thessaloniki, Greece (21 July 2017): pp. 532544 .

Chatzigeorgiou, C., Christou, E., \& Simeli, I. (2019): Confidence and loyalty for agrotourism brands: The Lesvos paradigm. Tourismos: An International Multidisciplinary Journal of Tourism, 14(1), 151-166, http://doi.org/10.5281/zenodo.3755067.

Chatzigeorgiou, C., \& Simeli, I. (2017). Perception of service quality in agrotourism accommodations: Impact on guest loyalty and re-visit intentions. Journal of Tourism, Heritage E Services Marketing, 3(1), 33-41, http://doi.org/10.5281/zenodo.401375.

Chen, H.J., \& Sasias, M. (2014). Tourist segmentation in Taiwan's wineries: A cultural perspective. Social Behavior and Personality: An International Journal, 42(2), 223-236, https://doi.org/10.2224/ sbp.2014.42.2.223.

Chen, X., Goodman, S., Bruwer, J., \& Cohen, J. (2015). Beyond better wine: The impact of experiential and monetary value on wine tourists' loyalty intentions. Asia Pacific Journal of Tourism Research, 21(2), 172-192.

Christou, E. (2002). Examining the impact of tourism destination image and reputation on visitor loyalty likelihood. Tourism Today, 2(1), 34-46.

Christou, E. (2011). Exploring the impact of visitor satisfaction on loyalty towards a specific destination. Acta Turistica, 23(1), pp.1-25.

Christou, E., Chatzigeorgiou, C., \& Simeli, I. (2018). Destination branding and visitor loyalty: The case of agrotourism. TOURMAN 2018 Conference Proceedings. Rhodes: Greece (28 October 2018), pp. 237245.

Christou, E., \& Nella, A. (2010a). A review of wine tourism research from 1995 to 2010: Analysis of 110 contributions. Journal of Hospitality and Tourism, 8(1), 112-123.

Christou, E., \& Nella, A. (2010b). Proposing an alternative service quality measurement scale for wine tourism experiences. Paper presented at the 2010 EuroCHRIE Conference, Stenden University, Amsterdam, 25-28 October.

Christou, E., \& Nella, A. (2016). Web 2.0 and pricing transparency in hotel services. In Sigala, M., Christou, E. and Gretzel, U. (Eds), Social Media in Travel, Tourism and Hospitality. Surrey: Ashgate Publishing, pp. 133-148.

Cohen, E., \& Ben-Nun, L. (2009). The important dimensions of wine tourism experience from potential visitors' perception. Tourism and Hospitality Research, 9(1), 20-31.

Collins, D. (2005). Tourism research Australia niche market report number 5. A profile of wine visitors in Australia 2003. Canberra: Tourism Research Australia.

Corigliano, A. (1996). Enoturismo: caratteristiche della domanda, strategia di offerta e aspetti territoriali e ambientali. Milano: Franco Angeli.

Daskalaki, V.V., Voutsa, M.C., Boutsouki, C., \& Hatzithomas, L. (2020). Service quality, visitor satisfaction and future behavior in the museum sector. Journal of Tourism, Heritage $\mathcal{E}$ Services Marketing, 6(1), 3-8.

Dawson, H., Holmes, M., Jacobs, H., \& Wade, R. (2011). Wine tourism: Winery visitation in the wine appellations of Ontario. Journal of Vacation Marketing, 17(3), 237-246. 
De Ridder, K., \& Vanneste, D. (2020). Tourism development through landscape theming: Exploring Art Nouveau experiences in Brussels. Journal of Tourism, Heritage E Services Marketing, 6(2), 45-54.

Del Chiappa, D., Usai, S., Cocco, A., \& Atzeni, M. (2018). Sustainable tourism development and climate change: A supply-side perspective. Journal of Tourism, Heritage E Services Marketing, 4(2), 3-9.

Dodd, T.H. (1998). Influences on search behavior of industrial tourists. Journal of Hospitality and Leisure Marketing, 5(2/3), 77-94.

Dodd, T.H. (1999). Attracting repeat customers to wineries. International Journal of Wine Marketing, $11(2), 18-28$.

Dreyer A. (2019). Wine plus tourism offers: It is not all about wine - wine tourism in Germany. In: Sigala M., \& Robinson R. (eds.), Wine Tourism Destination Management and Marketing. Cham: Palgrave Macmillan.

Ferreira, S.L.A., \& Hunter, C.A. (2017). Wine tourism development in South Africa: a geographical analysis. Tourism Geographies, 19(5), 676-698.

Festa, G., Shams, S.M.R., Metallo, G., \& Cuomo, M.T. (2020). Opportunities and challenges in the contribution of wine routes to wine tourism in Italy - A stakeholders' perspective of development. Tourism Management Perspectives, 33, 100585. https://doi.org/10.1016/j.tmp.2019.100585.

Fisher, R.J., \& Price, L.L. (1991). The relationship between international travel motivations and cultural receptivity. Journal of Leisure Research, 23(2), 193-208.

Fotiadis, A., \& Williams, R.B. (2018). "TiCoSa" a 3d matrix conceptual model to investigate visitors' perceptions in an athletic event. Journal of Tourism, Heritage E Services Marketing, 4(2), 32-36, http://doi.org/10.5281/zenodo.1490450.

Gadelrab, R., \& Ekiz, E. (2019). An investigation of key success factors for restaurant operations in Saudi Arabia. Journal of Tourism, Heritage E Services Marketing, 5(2), 27-35, http://dx.doi.org/10.5281/ zenodo.3601673.

Galloway, G., Mitchell, R., Getz, D., Crouch, G., \& Ong, B. (2008). Sensation seeking and the prediction of attitudes and behaviours of wine tourists. Tourism Management, 29(5), 950-966.

Getz, D., \& Brown, G. (2006). Critical success factors for wine tourism regions: A demand analysis. Tourism Management, 27(1), 146-158.

Giannopoulos, A., Skourtis, G., Kalliga, A., Dontas-Chrysis, D.M., \& Paschalidis, D. (2020). Co-creating high-value hospitality services in the tourism ecosystem: Towards a paradigm shift? Journal of Tourism, Heritage E Services Marketing, 6(2), 3-8.

Gómez, M., Pratt, M.A., \& Molina, A. (2019). Wine tourism research: a systematic review of 20 vintages from 1995 to 2014. Current Issues in Tourism, 22(18), 2211-2249.

Hall, C. M. (1996). Wine tourism in New Zealand, In J. Higham (Ed.), Proceedings of the Tourism Down Under II: A research conference, University of Otago, 109-119.

Heaney, L. (2003). Tapping the barrel: profiling domestic wine tourists. 1998-2001. BTR Tourism Research Report, 5(1), 39-43. Canberra: Bureau of Tourism Research.

Houghton, M. (2008). Classifying wine festival customers: Comparing an inductive typology with Hall's wine tourist classification. International Journal of Culture, Tourism and Hospitality Research, 2(1), 67-76.

IJspeert, R., \& Hernandez-Maskivker, G. (2020). Active sport tourists: Millennials vs baby boomers. Journal of Tourism, Heritage E Services Marketing, 6(2), 12-20.

Jaffe, E., \& Pasternak, H. (2004). Developing wine trails as a tourist attraction in Israel. International Journal of Tourism Research, 6(4), 237-249.

Kim, H., \& Bonn, M.A. (2016). Authenticity: Do tourist perceptions of winery experiences affect behavioral intentions? International Journal of Contemporary Hospitality Management, 28(4), 839859 . 
Liu, H.C.R., Jing, P.H.A., \& Chiu, Y.Y.A. (2015). Investigating wedding quality characteristics: Evidence from Kaohsiung. Journal of Tourism, Heritage $\mathcal{E}$ Services Marketing, 1(1), 10-15, http://doi.org/10.5281/zenodo.376325.

Lockshin, L., \& Spawton, T. (2001). Using involvement and brand equity to develop a wine tourism strategy. International Journal of Wine Marketing, 13(1), 72-81.

López-Guzmán, T., Vieira-Rodríguez, A., \& Rodríguez-García, J. (2014). Profile and motivations of European tourists on the Sherry wine route of Spain. Tourism Management Perspectives, 11(1), 63-68.

Loubser, S.S. (2004). The role of wine tourism in establishing a successful South African wine industry. Proceedings of the 2004 International Wine Tourism Conference, Margaret River, Australia, 2-5 May.

Lyons, A., \& Branston, C. (2006). Cross cultural change, adjustment and culture shock: UK to USA. Tourism: An International Interdisciplinary Journal, 54(4), 355-365.

Ma, E.J., Duan, B., Shu, L.M., \& Arcodia, C. (2017). Chinese visitors at Australia wineries: Preferences, motivations, and barriers. Journal of Tourism, Heritage \& Services Marketing, 3(1), 3-8, http://doi.org/10.5281/zenodo.401062.

Martins, M. (2016). Gastronomic tourism and the creative economy. Journal of Tourism, Heritage $\mathcal{E}$ Services Marketing, 2(2), 33-37.

Marzo-Navarro, M., \& Pedraja-Iglesias, M. (2010). Are there different profiles of wine tourists? An initial approach. International Journal of Wine Business Research, 22(4), 349-361.

Mavragani, E., Nikolaidou, P., \& Theodoraki, E. (2019). Traveler segmentation through social media for intercultural marketing purposes: The case of Halkidiki. Journal of Tourism, Heritage $\mathcal{E}$ Services Marketing, 5(1), 15-23, http://doi.org/10.5281/zenodo.2641011.

McGregor A., \& Robinson R.N.S. (2019). Wine industry and wine tourism industry collaboration: A typology and analysis. In: Sigala M., \& Robinson R. (eds.) Wine Tourism Destination Management and Marketing. Cham: Palgrave Macmillan.

McNamara, N., \& Cassidy, F. (2015). Wine tasting: To charge or not to charge? International Journal of Hospitality Management, 49(3), 8-16, http://dx.doi.org/10.1016/j.ijhm.2015.05.004

Mitchell, R., \& Hall, C.M. (2006). Wine tourism research: The state of play. Tourism Review International, 9(4), 307-332.

Montella, M.M. (2017). Wine tourism and sustainability: A Review. Sustainability, 9(1), 113-121.

Nella, A., \& Christou, E. (2014a). Linking service quality at the cellar door with brand equity building. Journal of Hospitality Marketing $\mathcal{E} \quad$ Management, 23(7), 699-721, http://dx.doi.org/10.108o/19368623.2014.891959.

Nella, A., \& Christou, E. (2014b). Segmenting wine tourists on the basis of involvement with wine. Journal of Travel E Tourism Marketing, 31(7), 783-798, http://dx.doi.org/10.1080/10548408. 2014.889639.

O’Neil, M., \& Palmer, A. (2004). Wine production and tourism: Adding service to a perfect partnership. Cornell Hotel and Restaurant Administration Quarterly, 45(3), 269-284.

Pakhalov, A., \& Rozhkova, N. (2020). Escape rooms as tourist attractions: Enhancing visitors' experience through new technologies. Journal of Tourism, Heritage $\mathcal{E}$ Services Marketing, 6(2), 55-6o.

Quadri-Felitti, D., \& Fiore, A. (2012). Experience economy constructs as a framework for understanding wine tourism. Journal of Vacation Marketing, 18(3), 78-89.

Quadri-Felitti, D. L., \& Fiore, A. M. (2013). Destination loyalty: Effects of wine tourists' experiences, memories, and satisfaction on intentions. Tourism and Hospitality Research, 13(1), 47-62.

Quadri-Felitti, D., \& Fiore, A.M. (2016). Wine tourism suppliers' and visitors' experiential priorities. International Journal of Contemporary Hospitality Management, 28(2), 397-417, https://doi.org/10.1108/IJCHM-05-2014-0224. 
Revilla Hernández, M., Santana Talavera, A., \& Parra López, E. (2016). Effects of co-creation in a tourism destination brand image through twitter. Journal of Tourism, Heritage \& Services Marketing, 2(2), 3-10. http://doi.org/10.5281/zenodo.376341.

Sigala, M., \& Christou, E. (2007). Exploiting Web 2.0 in open and distance education: Developing personalised and collaborative learning environments. In A. Lionarakis (Ed.), Proceedings of the 4 th International Conference on Open and Distance Learning-ICODL 2007 (pp.181-195). Athens: Propombos.

Smyczek, S., Festa, G., Rossi, M., \& Monge, F. (2020). Economic sustainability of wine tourism services and direct sales performance - emergent profiles from Italy, British Food Journal, 122(5), 1519-1529.

Scorrano, P., Fait, M., Maizza, A., \& Vrontis, D. (2019). Online branding strategy for wine tourism competitiveness. International Journal of Wine Business Research, 31(2), 130-150, https://doi.org/10.1108/IJWBR-o6-2017-0043.

Tassiopoulos, D., Nuntsu, N., \& Haydam, N. (2004). Wine tourists in South Africa: A demographic and psychographic study. Journal of Wine Research, 15(1), 51- 63.

Thomas, B., Quintal, V.A., \& Phau, I. (2016). Wine tourist engagement with the winescape. Journal of Hospitality \& Tourism Research, 40(4), 237-246, http://doi.org/10.1177/1096348016640583.

Thomson, M., McInnis, D.J., \& Park, C.W. (2005). The ties that bind: Measuring the strength of consumers' emotional attachments to brands. Journal of Consumer Psychology, 15(1), 77-91.

Valachis, I., Christou, E., Maroudas, L., \& Sigala, M. (2008). Assessment of training quality in hospitality industry: an exploratory model. In 26th EUROCHRIE Congress "Building a Legacy, Living the Dream".

Van Westering, J., \& Niel, E. (2003). The organization of wine tourism in France. Journal of Travel E Tourism Marketing, 14(3), 35-47.

Valeri, M. (2016). Networking and cooperation practices in the Italian tourism business. Journal of Tourism, Heritage \& Services Marketing, 2(1), 30-35, http://doi.org/10.5281/zenodo.376333.

Vo Thanh, T., \& Kirova, V. (2018). Wine tourism experience: A netnography study. Journal of Business Research, 83(1), 30-37.

Volgger, M., Pechlaner, H., \& Pichler, S. (2017). The practice of destination governance: A comparative analysis of key dimensions and underlying concepts. Journal of Tourism, Heritage $\mathcal{E}$ Services Marketing, 3(1), 18-24, http://doi.org/10.5281/zenodo.401371.

Wang, H., Wei, Y., \& Yu, C. (2008). Global brand equity model: Combining customer-based with product-market outcome approaches. Journal of Product and Brand Management, 17(5), 305-316.

Williams, P., \& Dossa, K. (2003). Non-resident wine tourist markets: Implications for British Columbia's emerging wine tourism industry. Journal of Travel and Tourism Marketing, 14(3/4), 1-34.

Yoo, B., \& Donthu, N. (2001). Developing and validating a multi-dimensional consumer-based brand equity scale. Journal of Business Research, 52(1), 1-14.

Yoo, B., Donthu, N., \& Lee, S. (200o). An examination of selected marketing mix elements and brand equity. Academy of Marketing Science, 28(2), 195-212.

Yuan, J., Cai, L.A., Morrison, A.M., \& Linton, S. (2005). Segmenting wine festival attendees: A factor cluster approach. Tourism Review International, 8(4), 297-311.

Yuan, J., Morrison, A., Cai, L.A., Dodd, T., \& Linton, S. (2008). Segmenting wine festival visitors using their personal involvement with wine. In Hall, C.M., \& Sharples, L. (Eds.), Food and Wine Festivals and Events Around the World: Development, Management and Markets. London: ButterworthHeinemann, pp.146-165.

Received: 09/03/2020

Accepted: 20/10/2020

Coordinating editors: Giacomo Del Chiappa and Anestis K. Fotiadis 